Труфанова Ю., Верба Т.

Національне законодавство у сфері нарахування заробітної плати

УДК 349.2

Юлія Труфанова,

викладач кафедри иивільного права і процесу юридичного факультету Тернопільського національного економічного університету

\title{
Тетяна Верба,
}

студентка групи ПРзм-21

юридичного факультету Тернопільського

національного економічного університету

\section{НАЦІОНАЛЬНЕ ЗАКОНОДАВСТВО У СФЕРІ НАРАХУВАННЯ ЗАРОБІТНОЇ ПЛАТИ}

Розглянуто питання у сфері нарахування заробітної плати, нормативно-правове закріплення основних актів, щчо визначають структуру заробітної плати та основні умови ї̈ виплати. Розглядаючи позиції науковців, в статті наведено сучасне розуміння поняття «заробітна плата» як юридична та сочіально-економічна категорія. Розглянуто базовий закон, щзо регулює відносини у сфері нарахування та виплати заробітної плати, надано поняття «заробітної плати» в рамках розглянутого Закону України «Про оплату праці». 3 дослідження вбачається окремий порядок нарахування суддівської винагороди, який регулюється нормами вищезгаданого Закону.

Ключові слова: заробітна плата, винагорода, суддівська винагорода, договірне регулювання заробітної плати.

Труфанова Ю., Верба Т.

Национальное законодательство в сфере начисления заработной платы

Рассмотрению вопросы в сфере начисления заработной платы, нормативно-правовое закрепление основных актов, которые определяют структуру заработной платы и основные условия ее выплаты. Рассматривая позиции ученых, в статье приведено современное понимание понятия «заработнаяплата» как юридическая и соичиально-экономическая категория. Рассмотрен базовый закон, который регулирует отношения в сференачисления ивыплаты заработнойплаты, предоставленопонятие «заработной платы» в рамках рассмотренного Закона Украинь «Об оплате труда». Из исследования видится отдельный порядок начисления судейского вознаграждения, который регулируется нормами выпеупомянутого Закона.

Ключевые слова: заработная плата, вознаграждение, судейское вознаграждение, договорное регулирование заработной платьл.

Trufanova Y., Verba T.

National legislation is in the field of extracharge of salary

The article is devoted to the consideration of issues in the area of wage calculation, the legal regulation of the basic acts defining the structure of wages and the main conditions for its payment. Considering the positions of scientists, the article gives a modern understanding of the concept of «wages» as legal on the one hand and socioeconomic from another category. The article deals with the basic law regulating relations in the field of accrual and payment of wages, provided the concept of «wages» within the framework of the considered Law of Ukraine «On Labor Remuneration». The study shows a separate procedure for the assessment of judges' remuneration, which is governed by the norms of the aforementioned law.

Keywords: wages, remuneration, judicial remuneration, contractual regulation of wages.

Постановка проблеми. Поряд з іншими інститутами трудового права, такими як, наприклад, трудовий договір, нормування праці та її охорона, винагорода за виконану роботу (заробітна плата) та їі нарахування посідають серед них центральне місце, адже вона, з одного боку, виступає компенсацією за витрачені працівником час та зусилля при виконанні роботи, а з іншого, - важливою гарантією держави, що забезпечує конституційне право на достатній життєвий рівень.

Основною причиною глибокої економічної, соціальної та політичної кризи в нашій країні є безладна система розподілу створеного сукупного продукту, непідконтрольність значної частки грошових доходів громади та відсутність продуктивної політики у сфері винагороди та оподаткування. Нормативно-правові акти 3 питань оплати праці, прийняті Кабінетом Міністрів та Верховною Радою України за останні роки, () Юлія Трифанова, Тетяна Верба, 2017 
повною мірою не забезпечують необхідну правову основу для розробки ефективної системи регулювання заробітної плати на підприємствах в різних галузях економіки з урахуванням загальних економічних та соціальних законів.

Останні дослідження. Проблема заробітної плати в Україні як в теоретичному, так і в практичному аспекті надзвичайно актуальна. Ця проблема була досліджена багатьма вченими: В. С. Василенком, О. С. Ветлужською, А. О. Гордєюком, Ю. М. М. Іванечко, П. М. Матюшко, А. І. Радчуком, Т. В. Сюзіковою, С. В. Цимбалюком та ін. У своїх працях вони всебічно розглядають найважливіші питання винагороди в сучасних економічних умовах. У той же час найбільшу увагу приділено вивченню основних чинників, що впливають на рівень заробітних плат громади. У вітчизняній економічній літературі немає єдиного підходу до сутності заробітної плати, особливостей його реалізації, вирішення проблем, що виникають на ринку праці у сфері їі диференціації, та інструментів державного регулювання, що веде до подальшого вивчення цього питання.

Мета статті - проаналізувати нормативно-правове регулювання нарахування заробітної плати.

Виклад основного матеріалу. Питання практичної реалізації нарахування заробітної плати виступають предметом дослідження багатьох науковців. Заробітна плата є багатоаспектним поняттям, відповідно наукове дослідження підходить до розуміння цього поняття з точок зору різних наук - юридичної чи економічної. В юридичному аспекті підхід до розуміння заробітної плати зводиться до узагальнення окремих правових норм, що стосуються закріплення в міжнародних нормативно-правових актах, визначення мінімальної заробітної плати, державного регулювання заробітної плати, мотиваційної функції заробітної плати та ін.

Характеризуючи категорію «гідне життя», Т. Юзько визначила основні умови гідної праці (зайнятість, достойна заробітна плата, впевненість у постійності роботи тощо), які є основними у сфері соціального буття людини. На її думку, забезпечення гідної праці завжди виражається наслідком гідного людського життя [1, с. 21].

Справедлива організація заробітної плати, дотримання правильних пропорцій, співвідношення заробітної плати з умовами та результатами праці служать потужним чинником стимулювання продуктивності праці, інтересу працівника до підвищення ефективності та якості виконуваної ним роботи. Таким чином, дослідження, проведені для виявлення пріоритетів мотивації працівників на підприємствах різних форм власності, показали, що основним пріоритетом роботи в сучасних умовах є його оплата, зокрема висока заробітна плата. Здатність особи самостійно використовувати свою здатність до праці для здійснення права на гідне життя забезпечується трудовим законодавством. Основні напрями впливу на суспільні відносини у сфері праці визначаються через функції трудового права, наголошуючи також на тому, що основною функцією трудового права є соціальна функція.

У своєму монографічному дослідженні О. А. Мельниченко охарактеризував сутність заробітної плати з позиції витрат роботодавця та чинника рівня і якості життя в контексті основного засобу для існування працюючого населення [2, с. 32].

Конвенція про захист заробітної плати поняття «заробітної плати» трактує як винагороду, обчислену в грошовому вигляді, що встановлена угодою чи законом на підставі трудового договору за виконану роботу [3].

Нормативне закріплення та легальну дефініцію заробітної плати наведено у ст. 1 Закону України «Про оплату праці», відповідно до якої це винагорода, обчислена, як правило, у грошовому виразі, яку за трудовим договором роботодавець виплачує працівникові за виконану ним роботу.

Розмір заробітної плати законодавець ставить у залежність зі складністю та умовами роботи, що виконує працівник, рівнем його професійно-ділових якостей та результатів його праці.

Структуру заробітної плати складають основна та додаткова заробітна плата та інші заохочувальні та компенсаційні виплати [4].

Положення Закону про оплату праці поширюються на усіх працівників, що виконують роботу за трудовим договором, незалежно від організаційно-правової форми підприємства, установ чи організацій.

Державне регулювання заробітної плати має бути спрямоване насамперед на створення умов для безперервного відтворення робочої сили необхідної якості та стимулювання високої продуктивності найманої праці працівників. Державою мають бути забезпечені відповідні законодавчі положення для запобігання виникнення спотворень у диференціації заробітної плати за категоріями, групами та професіями найманих працівників для виявлення причин (небажані тенденції, а також заходів щодо їх локалізації та ліквідації), нехтування роллю регулювання заробітної плати у забезпеченні розширеного стану (робоча сила є однією з важливих причин демографічної кризи, трудові міграції) та інші небажані явища. 
Труфанова Ю., Верба Т.

Національне законодавство у сфері нарахування заробітної плати

Постійні відставання темпів зростання продуктивності праці в Україні - цей показник в інших країнах світу викликає менш виражену динаміку, яка відповідає вимогам закону, однак не сприяє підвищенню продуктивності праці.

Договірне регулювання оплати праці здійснюється на основі системи угод, що укладаються відповідно до ст. 14 Закону «Про оплату праці» на таких рівнях: національному, тобто з укладенням та підписанням генеральної угоди; галузевому, до яких відноситься галузева чи міжгалузева угода; територіальному рівні; локальному - на підприємстві з укладанням колективного договору.

На підприємстві рівень заробітної плати встановлюється остаточно, тому цей рівень є насправді найважливішим як для працівника, так і для власника. Логічно було б сподіватися, що саме на цьому рівні інтереси працівника та власника узгоджуються зі збільшенням прибутку компанії, підвищення його конкурентоспроможності, з одного боку, та підвищення продуктивності, з іншого. Однак на рівні підприємства присутні всі недоліки. По-перше, небезпека прав власності та невизначеність перспектив зумовлюють бажання власника широко використовувати фактори виробництва, звідси - мінімізувати інвестиції як у основний, так і в людський капітал. По-друге, поширення недобросовісної конкуренції шляхом монополізації ринків, податкових та інших переваг тощо, спотворює взаємозв’язок між продуктивністю та ефективністю економічної діяльності, а отже, і між доходами підприємств та заробітною платою.

Працівники приватної сфери здебільшого прив'язані до мінімальної заробітної плати, визначаючи iii розмір для посадових окладів некваліфікованих працівників. Керівниками господарських підприємств практикується виплата мінімальної заробітної плати офіційно, а надлишок у конверті для зменшення податкового тиску на роботодавця.

Г. С. Колесник [5], розглядаючи особливості окремих груп працівників, що працюють в специфічній організації виробництва чи технологічних процесів, наголосив на доцільності встановлення певної форми оплати праці, наприклад, погодинної чи відрядної, пов'язуючи це зі створенням стимулів для підвищення продуктивності праці. Загалом заробітна плата відображає економічний стан населення, тому індексація впроваджується для іiі підтримки на певному рівні.

Таким чином, відповідно до ст. 97 КЗПП, форми та системи, норми праці, тарифи, тарифні ставки, схеми заробітної плати, умови введення та розмір надбавок, додаткові платежі, винагороди та інші стимули, компенсації та гарантійні платежі встановлюються підприємствами, установами, організаціями в колективній угоді, а у випадку, коли це не було укладено - власником або його уповноваженим органом за погодженням 3 профспілковим органом, що представляє інтереси більшості працівників, або у його відсутності з іншим органом умови та розмір винагороди працівників установ та організацій, що фінансуються з бюджету, визначаються урядом окремо [6].

Для робітників, що надежать до сфери, що фінансується з бюджету держави, їх посадові оклади встановлюються за тарифною сіткою, які пропорційно підвищуються залежно від збільшення розміру посадового окладу працівника, що належить до 1 розряду за тарифами Єдиної тарифної сітки розрядів і коефіцієнтів з оплати праці працівників установ, закладів та організацій окремих галузей бюджетної сфери, затвердженої Постановою Кабінету Міністрів України № 1298 від 30 серпня 2002 р. [7].

Окремо працівники установ, закладів та організацій освіти, науки та культури, які мають національний статус, заробітні плати розраховуються з урахуванням додаткового коефіцієнта ії підвищення відповідно до Постанови Кабінету Міністрів України № 1298 від 30 серпня 2002 р. [8].

О. Ю. Івашина [9], виділяючи основні риси державного регулювання індивідуальної оплати праці в бюджетній сфері, має базуватися на удосконаленні тарифної системи. Перегляд мінімальної заробітної плати має супроводжуватися відповідною зміною фонду заробітної плати конкретного бюджетного підприємства чи установи з метою збереження встановленого рівня диференціації винагороди. Важливим напрямом у реформуванні організації оплати праці працівників бюджетної сфери має стати посилення позиції та ролі актів соціального партнерства.

Порушуючи питання регулювання оплати праці, Г. І. Чанишевою [10] запропоновано «колективнодоговірне регулювання оплати праці». Так, вчена, досліджуючи колективні трудові відносини, запропонувала дефініцію колективних трудових відносини, характеризуючи їх як регульовані нормами трудового законодавства соціальні відносини, що виникають у процесі реалізації їх суб'єктами трудових прав відповідно до чинного законодавства.

Порядком виплати надбавки працівникам закладів (організацій) фізичної культури і спорту інвалідів за вислугу років у сфері фізичної культури і спорту інвалідів визначено механізм призначення і виплати надбавки працівникам закладів (організацій) фізичної культури і спорту інвалідів за вислугу років у сфері фізичної культури і спорту інвалідів. 
Таким чином, розмір грошової виплати працівникам закладів (організацій) фізичної культури та спорту інвалідів, що включає центри фізичної культури та спорту інвалідів «Інваспорт», Національний комітет спорту інвалідів, підприємство Національного Комітету спорту інвалідів «Західний центр реабілітації та спорту» сплачується щомісяця у відсотках від посадового ставки, залежно від тривалості роботи у таких розмірах: понад 3 роки -10\%, більше 10 років - 20\%, більше 20 років - 30\% [11].

Для працівників бюджетної сфери, які є державними службовцями, заробітна плата сплачується відповідно до ст. 50 Закону України «Про державну службу», згідно з якою у структурі заробітної плати державного службовця входять заробітна плата, заробітна плата; ранг, оплата додаткового робочого навантаження у зв'язку з виконанням обов'язків тимчасово відсутнього державного службовця або виконання ним своїх обов’язків за вакантну посаду державної служби, премії (у разі встановлення) [12].

Окрему категорію становлять судді, на них не поширюється інше законодавство у сфері нарахування заробітної плати, крім Закону України «Про судоустрій і статус суддів». Так, відповідно до ст. 135 Закону, суддівська винагорода виплачується судді з дня зарахування його до штату відповідного суду.

Винагороди суддів складаються із окладу відповідної посади та додаткових виплат за: 1) стаж роботи (вислугу); 2) перебування в адміністративній посаді в суді; 3) якщо суддя має науковий ступінь; 4) роботи, які передбачають доступ до державної таємниці.

Законом встановлюються коефіцієнти до окладів в залежності від посади в судовій інстанції, в якій працює суддя [13].

Висновок. Таким чином, національне законодавство у сфері нарахування заробітної плати основане на міжнародно-правових договорах, Конституції України, Кодексу законів про працю, Закону України «Про оплату праці», постанов Кабінету Міністрів України в сфері нарахування заробітної плати та інших нормативно-правових актів. Законодавець, визначаючи порядок нарахування заробітної плати, визначив іiі структуру, до якої відніс основну й додаткову заробітну плату, інші заохочувальні та компенсаційні виплати. Державою встановлення рівня мінімальної заробітної плати гарантується як конституційна засада, через що працівникам бюджетної сфери посадовий оклад прив'язується до прожиткового мінімуму, встановленого на 1 січня відповідного року. Однак така практика призводить до негативних наслідків, бо за рахунок доплат до мінімальної заробітної плати скорочується фонд оплати праці, що призводить до мінімального розриву в окладах кваліфікованих працівників з великим стажем роботи поряд з некваліфікованими працівниками. 3 дослідження вбачається, що норми Закону України «Про оплату праці» не поширюються на суддів.

\section{Список використаної літератури}

1. Юзько Т. Гідна оплата праці як необхідний атрибут захисту права на життя працівника / Т. Юзько // Підприємництво, господарство і право. - 2015. - № 8. - С. 21-25.

2. Мельниченко О. А. Підвищення рівня та якості життя населення: механізм державного регулювання : моногр. / О. А. Мельниченко. - Х. : Вид-во ХарРІ НАДУ «Магістр», 2008. - 232 с.

3. Конвенція про захист заробітної плати № 95 (укр/рос) [Електронний ресурс]. - Режим доступу : http://zakon5.rada.gov.ua/laws/show/993_146.

4. Про оплату праизі : Закон в редакиії від 01.01.2017 p. [Електронний ресурс]. - Режим доступу : http:// zakon5.rada.gov.ua/laws/show/108/95-\%D0\%B2\%D1\%80.

5. Колесник Г. С. Проблеми оплати праці на підприємствах залізничного транспорту України / Колесник Г. С. [Електронний ресурс]-Pежим доступy : http://cyberleninka.ru/article/n/problemi-oplati-pratsi-napidpriemstvah-zaliznichnogo-transportu-ukrayini.

6. Кодекс законів про працю України : Закон в редакції від 02.12.2017 р.[Електронний ресурс]. - Режсм docmyny : http://zakon3.rada.gov.ua/laws/show/322-08.

7. Про упорядкування структури заробітної плати, особливості проведення індексації та внесення змін до деяких нормативно-правових актів: Закон в редакції від 06.09.2017 p. [Електронний ресурс]. - Режим достуny : http://zakon5.rada.gov.ua/laws/show/1013-2015-\%D0\%BF.

8. Постанова Кабінету Міністрів України № 1298 від 30 серпня 2002 р. «Про оплату праці працівників на основі Сдиної тарифної сітки розрядів і коефіцієнтів з оплати праџі працівників установ, закладів та організацій окремих галузей бюджетної сфери» [Електронний ресурс]. - Режим доступу : httр:// zakon5.rada.gov.ua/laws/show/1298-2002-\%D0\%BF/paran79\#n79.

9. Івашина О. Ю. Державне регулювання індивідуальної оплати праці в Україні / О. Ю. Івашина // Публічне адміністрування: теорія та практика : електр. зб. наук. пращь. - 2010. - №. 1 (3) [Електронний ресурс]. - Режим доступy : htt: //www.dridu.dp.ua/zbirnik/2010-01/1. 
Труфанова Ю., Верба Т.

Національне законодавство у сфері нарахування заробітної плати

10. Чанишева Г. І. Колективні відносини у сфері праці: теоретичні та практичні проблеми правового регулювання: автореф. дис. на здобуття наук. ступеня д-ра юрид. наук: спец. 12.00 .05 «Трудове право; право сочіального забезпечення» / Г. І. Чанишева. - Харків, 2002. - 22 с.

11. Постанова Кабінету Міністрів Украӥни № $820 в і д 16$ листопада 2016 р. «Про Порядок виплати надбавки працівникам закладів (організащій) фізичної культури і спорту інвалідів за вислугу років у сфері фізичної культури і спорту інвалідів» [Електронний ресурс]. - Режим доступу : http://zakon5.rada.gov. ua/laws/show $/ 820-2016-\% D 0 \%$ BF.

12. Про державну службу: Закон в редакиії від 15.11.2017 p. [Електронний ресурс]. - Режим доступу : http://zakon3.rada.gov.ua/laws/show/889-19/page3.

13. Про судоустрій і статус суддів : Закон в редакиї від 29.11.2017 [Електронний ресурс]. - Режим доcmyny : http://zakon3.rada.gov.ua/laws/show/1402-19/page5.

\section{References}

1. Yuzko T. (2015). Gidna oplata praci yak neobchidnui atribut yakosti [Dilable pay as a necessary attribute of protection of the right to worker's life].Entrepreneurship, economy and law, 8, 21-25. [in Ukrainian].

2. Melnichenko O. A. (2008) Pidvishennya rivnya ta yakosti juttya naselennya: mechanism derzavnogo regulyvannya [Improving the level and quality of life of the population: the mechanism of state regulation]. Kharkiv. Ukraine: "Magister».[in Ukrainian].

3. Konvenciya pro zachist zarobitnoi platy : pryinyata 23.06.1992 № 95. [Convention on the Protection of Wages] (1992, June, 23). Retrieved from http://zakon5.rada.gov.ua/laws/show/993_146[in Ukrainian].

4. Zakon Ukrainy pro oplatu praci: pryinyatyi 24 ber.1995 roku № 108/95-BP [Law of Ukraine About the payment of wages, № 108/95-VR] (1995, March, 24).Retrieved from http://zakon5.rada.gov.ua/laws/show/108/95$\%$ D0\%B2\%D1\%80[in Ukrainian].

5. Kolesnik G.S. Problemy oplaty praci na pidpriemstvach zaliznichnogo transport Ukrainy [Problems of Remuneration at Railway Facilities Enterprises of Ukraine]. Retrieved from http://cyberleninka.ru/article/n/ problemi-oplati-pratsi-na-pidpriemstvah -zaliznichnogo-transport-ukrayini [in Ukrainian].

6. Kodeks zakoniv pro pracyu: pryinyatyi 10.dec.1971 № 322-VII[Code of Labor Laws of Ukraine] (1971, December, 10). Retrieved from http://zakon3.rada.gov.ua/laws/show/322-08 [in Ukrainian].

7. Pro uporyadkuvannya strukturu zarobitnoi platu, osobluvosty provedennya indeksacii ta vnesennya zmin do deyakich normatyvno-pravovych aktiv: pryinyatyi 09.dec.2015 № 1013[Resolution of the Cabinet of Ministers of Ukraine On the ordering of the structure of wages, the peculiarities of indexation and amendments to certain legal acts№ 1013] (2015, December, 09). Retrieved from http://zakon5.rada.gov.ua/laws/show/1013-2015-\%D0\%BF [inUkrainian].

8. Pro oplatu praci pracivnukiv na osnovi edunoi tarufnoi sitku rozryadiv I koeficientiv z oplatu praci pracivnukiv ustanov, zakladiv ta organizacii okrenuch galyzei budzhennoi sfery: pryinyatyi30. avg.2002 №1298 [Resolution of the Cabinet of Ministers of Ukraine On the payment of workers on the basis of the Unified Tariff Grid and coefficients for the remuneration of employees of institutions, institutions and organizations of certain branches of the budget sphere№1298]. (2002,August, 30). Retrieved fromhttp://zakon5.rada.gov.ua/laws/show/1298-2002-\%D0\%BF/paran79\#n79[in Ukrainian].

9. Ivashina O. Y. (2010). Derzhavne regulyvannya induvidualnoi oplatu praci v Ukraine [State regulation of individual wages in Ukraine].Public Administration: Theory and Practice: Electr. save sciences works, 1 (3). Retrieved fromhttps://www.dridu.dp.ua/zbirnik/2010-01/1.[in Ukrainian].

10. Chanisheva G. I. (2002) Kolectuvni vidnosunu y sferipraci: teoretuchni ta practuchni problem pravovogo regulyuvannya [Collective relations in the field of work: theoretical and practical problems of legal regulation: author's abstract. dis for obtaining sciences]. Extended abstract of doctor's thesis. Kharkiv[in Ukrainian].

11. Pro poryadok viplatu pracivnucam zakladiv (organizacii) fizychnoi cultury I sporty invalidiv za vuslugu rokiv u sferifizychnoi cultury I sporty invalidiv:pryinyatyi 16. noyab.2016№820[Resolution of the Cabinet of Ministers of UkraineOn the Procedure for Payment of Supplements to Employees of Physical Culture and Sport Institutions (Disabled Persons) for Disciplinary Disabilities in the Field of Physical Culture and Sport of Disabled Persons№ 820] (2016, November, 16). Retrieved from http://zakon5.rada.gov.ua/laws/show/820-2016-\%D0\%BF[in Ukrainian].

12. Zakon Ukrainy pro derzhavny sluzhby: pryinyatyi10.dek. 2015roku № 889-VIII ( 889-19) [Law of Ukraine About the civil service] (2015, December, 10). Retrieved from http://zakon3.rada.gov.ua/laws/show/889-19/page3[in Ukrainian].

13. ZakonUkrainy pro sudoustrii ta status suddiv: pryinyatyi02.iyul. 2016roku № 1402-VIII[Law of Ukraine On the Judiciary and the Status of Judges, № 1402-VIII] (2016, July, 02). Retrieved from http://zakon3.rada.gov. ua/laws/show/1402-19/page5[in Ukrainian].

Стаття надійшла до редакції 20.11.2017. 